DOI $10.15421 / 4221005$

УДК 539.3

\author{
А. П. Дзюба, д-р техн. наук, А. Г. Пацюк, канд. техн. наук
}

\title{
ЕКСПЕРИМЕНТАЛЬНЕ МОДЕЛЮВАННЯ ПРОЦЕСУ ВИНИКНЕННЯ ТРІЩИНИ НА КОНТУРІ ОТВОРУ 3 ВКЛЮЧЕННЯМ
}

Моделюється процес утворення тріщини в зразках із оптично активного матеріалу на контурі кругового отвору пластини із полікарбонату 3 використанням включень 3 матеріалу, виготовленого на основі епоксидної смоли. Дослідження проводились шляхом спільного використання поляризаційно-оптичного методу та методу каустик. Досліджено крихке і пластичне руйнування зразків в результаті появи і розвитку тріщини. Отримані залежності J-інтегралу від величини навантаження зразка на згинання. Вивчено вплив закріплення включень жорстким та еластичним клеями. Викладена методика експериментальних досліджень. Результати подані у вигляді графіків та картин ізохром і каустик.

Ключові слова: експериментальне моделювання тріщин; крихке і пластичне руйнування; концентратори напружень; отвори; включення; поляризаційнооптичний метод; метод каустик.

Вступ. Забезпечення міцності елементів конструкцій $є$ однією з найважливіших задач механіки. Руйнування деформівних тіл $є$ надзвичайно складним процесом деформації, при якому матеріал фрізично розділяється на частини в результаті появи тріщин, внаслідок чого здатність конструкції нести зовнішнє навантаження знижується до нуля. Однією 3 особливостей руйнування та кінетики розвитку тріщини є ії катастрофічно швидкий ріст, що суттєво ускладнює вивчення процесу їх утворення i розвитку. Зважаючи, що поява тріщин в процесі експлуатації може привести до катастрофрічних наслідків, вивченню процесу появи і розвитку тріщин присвячена значна кількість наукових досліджень [1 - 4, 6 - 10].

Відповідно до критерію Гріффрітса (1920р.) в деформованому крихкому тілі тріщина починає рости при такому напруженому (критичному) стані, коли швидкість вивільнення енергії пружної деформації тіла під час ії̈ зростання перевищує приріст поверхневої енергії тіла на поверхнях тріщини, що утворюються внаслідок її розкриття.

У той же час для квазікрихких матеріалів, зокрема для сталей, цей критерій не відповідає дійсності. Дж. Ірвін (1948р.) і Е. Орована (1955 р.) звернули увагу, що у квазікрихких матеріалах перед краєм тріщини з'являється певна зона пластичних деформацій, що інтенсивно поглинає вивільнену енергію і цим уповільнює рух тріщини.

Таким чином, процес руйнування складається із сукупності явищ, які можуть починатись значно раніше, ніж з'являються перші візуально помітні тріщини. При цьому, причинами появи таких тріщин можуть бути 
дефекти в структурі матеріалу, мікропустоти, включення, раковини, корозійні ураження та інші пошкодження. Поява тріщин може бути обумовлена також конструктивними недоліками, зокрема, наявністю концентраторів напружень.

Подана стаття присвячена розробці методики експериментального дослідження зазначених вище явищ.

Експериментальні дослідження. На сьогодні для розрахунку міцності і довговічності конструкцій з тріщинами використовуються основні співвідношення механіки руйнування [1, 3, 7]. При цьому, як правило, відшукуються такі основні параметри: коефіцієнт інтенсивності напружень (КІH); Ј-інтеграл, що визначає інтенсивність вивільнення пружної енергії, яка залежить від характеру і рівня навантаження, а також від довжини тріщини [3, 5, 7, 9]. У подальшому на основі експериментальних даних, що визначають опір матеріалу зростанню тріщини, які виражаються в термінах вказаних вище параметрів, знаходять міцність та довговічність елементів конструкції [6, 9].

Одним із можливих варіантів знаходження експериментальних даних $\epsilon$ моделювання процесу утворення і росту тріщини в зоні концентратора напружень.

Згідно концепції Гріффрітса - Орована - Ірвіна умова зростання тріщини при деформації плоскої пластини подається [3, 5, 9] у вигляді

$$
\frac{\sigma^{2} \pi l^{2}}{E} \geq 4 l\left(w_{H}+w_{n}\right),
$$

де $\sigma$ - напруження в пластині; $E$ - модуль пружності матеріалу; $2 l$ довжина тріщини; $w_{н}$ - енергія поверхневого натягу тріщини; $w_{n}$ - робота пластичної деформації; ліва частина (1) - це зменшення пружної енергії в пластині приведеної одиночної товщини при раптовому виникненні тріщини довжиною $2 l$; права частина (1) - це приріст енергії для створення нової поверхні з поверхневим натягом $w_{H}$.

Згідно до існуючих на сьогодні поглядів на енергетичний баланс розвитку тріщини, головний вплив визначає робота $w_{n}$, яка іде на пластичну деформацію при розповсюдженні тріщини.

Таким чином, змінюючи параметри правої частини (1), з'являється можливість для дослідження поведінки реальної тріщини.

Такі підходи до прогнозування руйнування матеріалу конструкції розвиваються в даний час досить інтенсивно. Однак, при зазначеному підході порушуються умови лінійної механіки про малість (або відсутність) зони пластичної деформації в околі тріщини. Тому, поряд з використанням лінійної моделі розкриття тріщини, віддається перевага нелінійній механіці руйнування. Теоретичний аналіз енергетичних затрат в околі тріщини, виконаний Г. П. Черепановим [8] і J. R. Rice [10] за допомогою контурного інтегралу, основаному на визначенні J-інтегралу (Черепанова - Райса), допускає можливість присутності пластичних деформацій та використання Ј-інтегралу в якості одного із критеріїв руйнування. 
В поданій роботі проведено експериментальне дослідження для визначення залежності значення Ј-інтегралу від величини навантаження при випробуваннях зразків з концентраторами напружень на згинання методом каустик [5], а також дослідження впливу включень у вигляді циліндричних вставок в кругові отвори як концентраторів напружень. Матеріал для цих вставок виготовлявся на основі епоксидної смоли 3 модулем пружності $E=2,9 \cdot 10^{9} \mathrm{H} / \mathrm{M}^{2}$. Вставки-включення приклеювались двома видами клеїв - жорстким двокомпонентним Akfix 705 і більш пластичним однокомпонентним 808. Результати цих досліджень порівнювались 3 даними випробувань зразків, у яких отвори прорізались 3 двох сторін на глибину $1 / 3$ товщини зразка. Тобто включення у цьому випадку імітувалось однорідною з матеріалом вставкою вказаної товщини без приклеювання.

Для проведення експерименту були виготовлені прямокутні моделі 3 полікарбонату (рис. 1) наступних геометричних розмірів: довжина $14 \cdot 10^{-2} \mathrm{M}$, ширина $45 \cdot 10^{-3} \mathrm{M}$, товщина $6 \cdot 10^{-3} \mathrm{M}$.

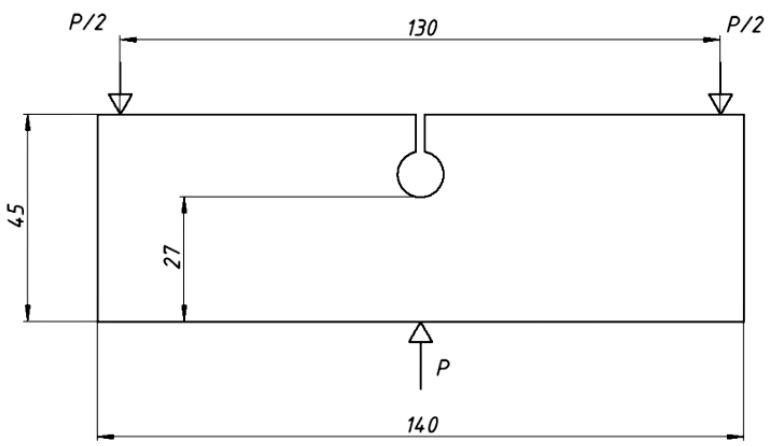

Рис. 1 - Зразок для випробувань

Зразок по ширині умовно був поділений на дві частини: нижню і верхню. У верхній частині розташовувався концентратор напружень у вигляді кругового вирізу радіусу $R=6,25 \cdot 10^{-3} \mathrm{M}$. Послідовність підготовки зразків до експерименту була наступною:

виготовлення зразків зазначеного розміру та свердління отвору заданого діаметру;

$0,1 \cdot 10^{-3}$ м діаметром отвору;

- приклейка включень двома видами клеїв;

- витончення зразка 3 двох сторін до 1/3 товщини зразка на місці основного отвору;

- $\quad$ свердління в центрі включень отвору діаметром $2 \cdot 10^{-3} \mathrm{M}$;

- прорізка верхньої частини зразків до основного отвору, а для зразків з включенням - до отвору у центрі включення. 
Навантаження зразків на згинання проводилось за допомогою реверсу на пресі УП-5 з кроком $5 H$ (рис. 2). Верхні дві призми, через які здійснювалось навантаження, були розташовані симетрично відносно осі симетрії зразка на відстані $I=13 \cdot 10^{-2} \mathrm{M}$, а нижня призма - на осі симетpiї. Реєстрація напружено-деформованого стану в околі отворівконцентраторів проводилась методом каустик [6].

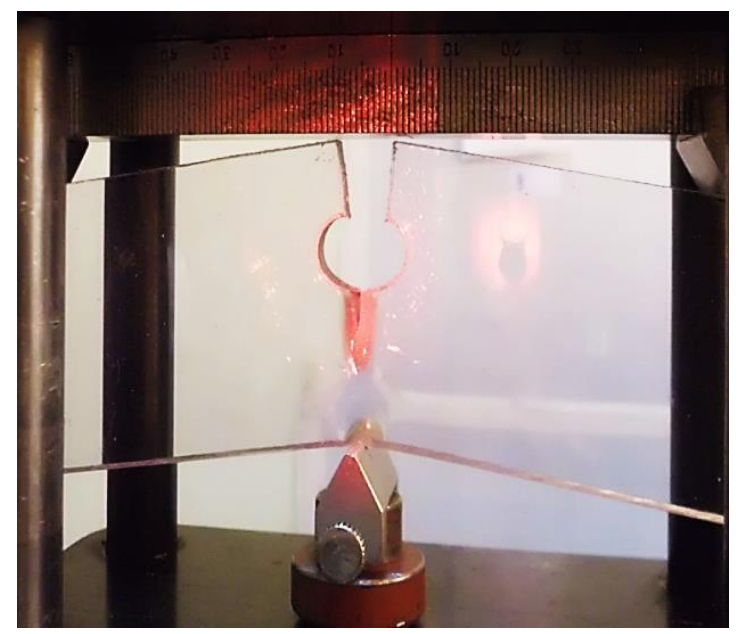

Рис. 2 - Випробування зразка на згин

Отримані результати експерименту подані у вигляді картин розподілу поля пластичних деформацій (рис. 3) та графіку залежності Jінтегралу від навантаження (рис. 4). Графрік складається з двох ділянок, де лінійний відрізок графріку відповідає пружним деформаціям, значення яких отримані за допомогою КІН та даних експерименту (рис. 3, а-в). Нелінійний відрізок графріку відповідає пружно-пластичному деформуванню матеріалу (рис. 3, г-з) і визначається через залежності для Jінтегралу [6].

Крихке руйнування відбувалось за умови встановлення в круговий отвір включення з епоксидної смоли з модулем пружності в 1,26 разів більшим від його значення для полікарбонату, а також склеювання поверхонь отвору зразка та включення жорстким клеєм.

Ці два фактори, на наш погляд, на етапі навантаження сприяли накопиченню пружної енергії в зоні між більш жорстким включенням і пружною поверхнею зразка. На рис. 5 видно, що в нижній лівій частині зразка відбувається зародження і фрормування тріщини, яке переросло в крихке руйнування при навантаженні в $750 \mathrm{H}$ (рис. 6).

Для випадку випробування поведінки зразків з включеннями, з'єднаними з отвором за допомогою більш пластичного клею, на початковому етапі навантаження (рис. 7, а) суттєвих відмінностей у порівнянні з випадком жорсткого з'єднання не спостерігалось. При середніх навантаженнях відбувається відокремлення включення від основного тіла зразка 
(рис. 7,6 ) і формування пластичної зони. При максимальному навантаженні сформувалась значна пластична зона між зоною включення і зоною локального прикладання навантаження. При цьому ця зона зміщувалась в бік поверхні, яка відокремлювалась (рис. 7, в).

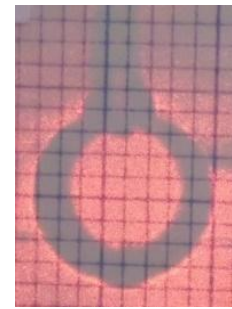

a)

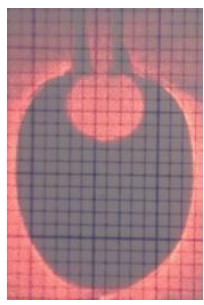

д)

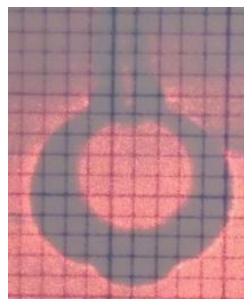

б)

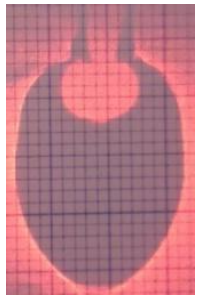

e)

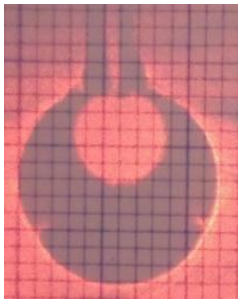

в)

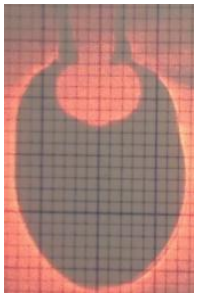

ж)

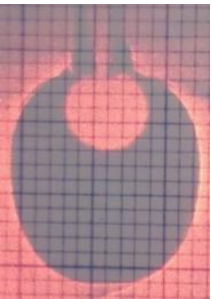

г)

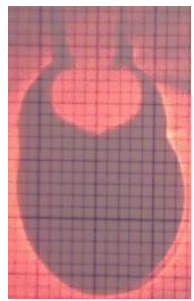

3)

Рис. 3 - Картини каустик в зоні концентратора напружень, які описуються J-інтегралом, при послідовному збільшенні навантаження

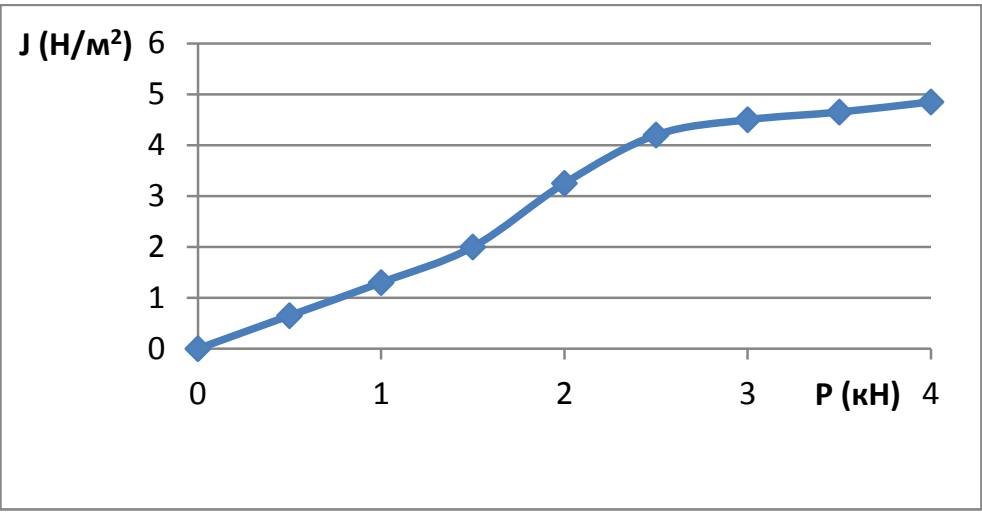

Рис. 4 - Графік залежності J-інтегралу від навантаження 


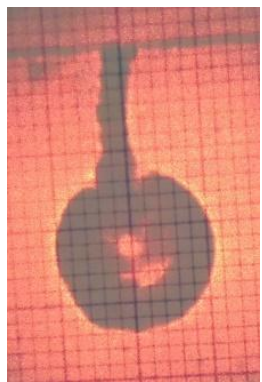

a)

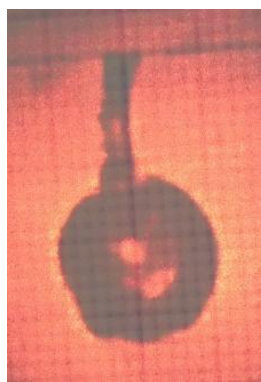

б)

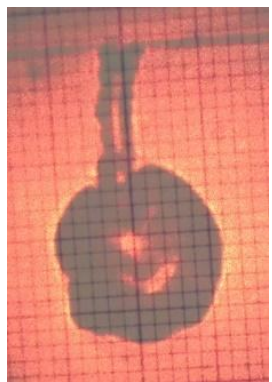

в)

Рис. 5 - Картини каустик перед крихким руйнуванням

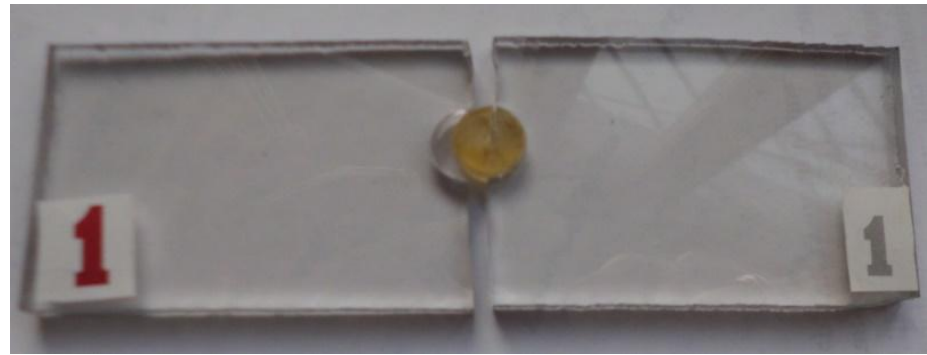

Рис. 6 - Зразок після крихкого руйнування

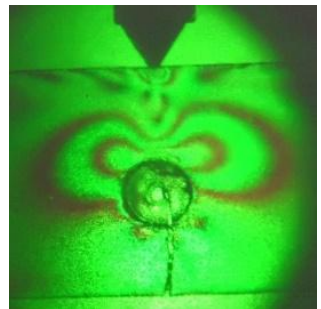

a)

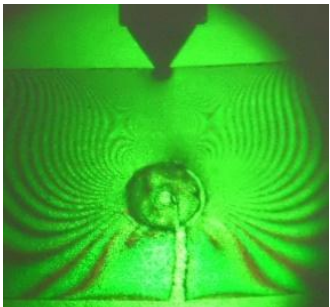

б)

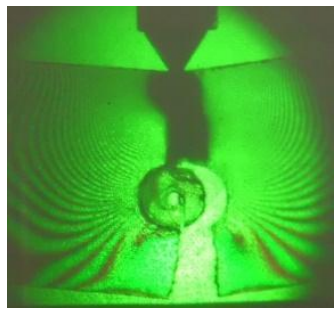

B)

Рис. 7 - Картини ізохром при навантаженні зразка 3 включенням

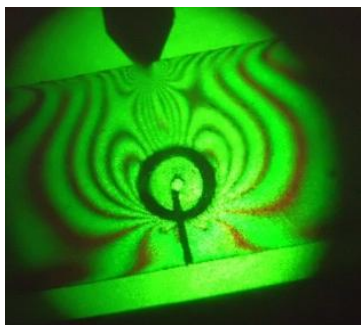

a)

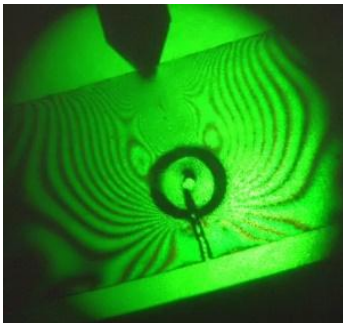

б)

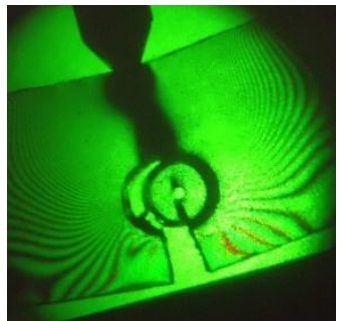

B)

Рис. 8 - Картини ізохром при навантаженні зразка без отвору з витонченням 
На рис. 8 подані картини ізохром при навантаженні зразка без отвору з витонченням матеріалу у цій зоні. Видно, що в центрі витончення біля отвору при середніх навантаженнях фрормується пластична зона (рис. 8, б). При максимальному навантаженні відбувалось відокремлення половини витончення і сформувалась пластична зона (рис. 8, в).

Висновки. За результатами проведених досліджень встановлено:

- напружено-деформований стан в околі тріщини в значній мірі характеризується наявністю пластичних деформацій;

- для J-інтегралу, який $є$ мірою деформованого стану в околі тріщини, можна виділити лінійну і нелінійну складові в залежності від рівня навантаження: перша в більшій мірі відповідає за пружні, а друга - за пластичні деформації;

- наявність включень, у яких модуль пружності є більшим, ніж в основному тілі зразків, при умові фріксації їх у зразках за допомогою жорстких клеїв, на відмінну від більш пластичних, може привести до крихкого руйнування по лінії з'єднання з переростанням в основне тіло зразка;

- зазначена послідовність створення включення може бути спусковим механізмом крихкого руйнування;

- витончення зразків по лінії основного отвору призводить до зменшення руйнівного навантаження пропорційно величині витончення.

Проведені експерименти вказують, що змінюючи жорсткісні параметри включень і клеїв можна моделювати різні аспекти процесів утворення тріщин в зразках і їх руйнування.

У цілому результати проведених експериментальних досліджень дозволяють встановити співвідношення величин пружних і пластичних десрормацій в процесі руйнування зразків та прогнозувати величини руйнівних навантажень.

\section{БІБЛІОГРАФІЧНІ ПОСИЛАННЯ}

1. Броек Д. Основы механики разрушения. Пер с англ. М.: Высшая школа, 1980. $386 \mathrm{c}$.

2. Лобода В.В. та ін. Проблеми механіки руйнування композитів з тріщинами на меж розподілу матеріалів. В кн. Актуальні проблеми механіки руйнування: монографія / під ред. М.В. Полякова. Д.: Ліра. 2018. С. 277-308.

3. Механика разрушения и прочности материалов: справочник у 4-х т. / Під ред. В.В. Панасюка. К.: Наукова думка, 1988. Т. 2. 620 с.

4. Моссаковский В.И., Рыбка М.Т. Обобщение критерия Гриффитса - Снеддона на случай неоднородного тела // Прикл. математика и механика. 1964. Т. 28. № 6. C. 1061-1069.

5. Пестриков В.М., Морозов Е.М. Механика разрушения твердых тел: курс лекцій. Санкт-Петербург: Профессия, 2002. 320 с.

6. Спосіб комбінованого визначення порогового коефіцієнту інтенсивності напружень у зразках з полікарбонату. Патент на корисну модель Uа № 141655 від 27.04.2020. Бюл. № 8. Авт.: Дзюба А.П., Пацюк А.Г., Полішко О.М.

7. Черепанов Г. П. Механика разрушения. Ижевск: Ин-т компьютерних исследований, 2012. 872 с.

8. Черепанов Г. П. О распространении трещин в сплошной среде // Прикл. математика и механика. 1967. Т. 31, вып. 3. С 111-116.

9. Экспериментальная механика: В 2-х кн.: Кн. 1. Пер. с англ./ Под ред. А. Кобаяси. М.: Мир, 1990. 612 с.

10. Rice J. R. A path independent integral and the approximate analysis of strain concentration by notches and cracks // J. Appl. Mech. 1968. Vol. 35. P. 379-386. 


\section{А. П. Дзюба, д-р техн. наук, А. Г. Пацюк, канд. техн. наук ЭКСПЕРИМЕНТАЛЬНОЕ МОДЕЛИРОВАНИЕ ПРОЦЕССА ОБРАЗОВАНИЯ ТРЕЩИНЫ НА КОНТУРЕ ОТВЕРСТИЯ С ВКЛЮЧЕНИЕМ}

Моделируется процесс образования трещины в образцах из оптически активного материала на контуре кругового отверстия пластины из поликарбоната с использованием включений из материала, изготовленного на основе эпоксидной смолы. Исследования проводились путем совместного использования поляризационно-оптического метода и метода каустик. Исследовано хрупкое и пластическое разрушение образцов в результате появления и развития трещины. Получены зависимости Ј-интеграла от величины нагрузки образца на изгиб. Исследовано влияние закрепления включений жестким и эластичными клеями. Изложена методика экспериментальных исследований. Результаты представлены в виде графиков и картин изохром и каустик.

Ключевые слова: экспериментальное моделирование трещин; хрупкое и пластическое разрушение; концентраторы напряжений; отверстия; включение; поляризационно-оптический метод; метод каустика.

UDC 539.3

A. P. Dzyuba, Dr. Sci. (Tech.), A. G. Patsyuk, PhD (Tech.)

\section{EXPERIMENTAL MODELING OF CRACK ARISING PROCESS AT THE HOLE WITH INCLUSION}

The process of creating a crack in specimens of an optically active material on the contour of a circular hole in a polycarbonate plate is simulated using inclusions from a material based on epoxy resin. The studies were carried out by using the polarization-optical method and the caustic method together. The brittle and plastic fracture of specimens as a result of the appearance and development of a crack has been investigated. The dependences of the J-integral on the value of the specimen bending load are obtained. The effect of fixing inclusions with hard and elastic adhesives has been investigated. The technique of experimental research is stated. The results are presented in the form of graphs and pictures of isochrom and caustic.

Keywords: experimental modeling of cracks; brittle and plastic destruction; stress concentrators; holes; inclusion; polarization optical method; caustic method.

Introduction. Ensuring the strength of structural parts is one of the most important tasks of mechanics. One of the features of fracture and kinetics of crack propagation is catastrophically rapid growth, which significantly complicates the study of the process of their formation and development. Considering that the appearance of cracks during operation can lead to catastrophic consequences, a significant number of scientific investigations are devoted to the study of the process of the appearance and development of cracks [1 - 4, 6-10].

One of the possible options for obtaining experimental data is to simulate the process of crack formation and growth in the stress concentrator zone. 
Experimental research. According to the concept of Griffiths - Orawan - Irwin, the condition of crack growth during deformation of a flat plate is given $[3,5,9]$ in the form

$$
\frac{\sigma^{2} \pi l^{2}}{E} \geq 4 l\left(w_{H}+w_{n}\right),
$$

where $\sigma$ is the stress in the plate; $E$ - modulus of elasticity of the material; $2 l$ - crack length; $w_{H}$ - the energy of the surface tension of the crack; $w_{n}-$ work of plastic deformation; the left part (1) is a decrease in elastic energy in a plate of reduced single thickness in the event of a sudden appearance of a crack of length $2 l$; the right side (1) is the energy increment to create a new surface with surface tension $w_{H}$.

According to the current views on the energy balance of crack propagation, the main influence is determined by the work $w_{n}$ that spends on plastic deformation during crack propagation.

Thus, by changing the parameters of the right-hand side of (1), it becomes possible to study the behavior of a real crack.

In this work, an experimental study was carried out to determine the dependence of the value of the J-integral on the magnitude of the load when testing specimens with concentrators of bending stresses by the caustic method [5], and also the study of the influence of inclusions in the form of cylindrical inserts in circular holes as stress concentrators. The material for these inserts was made on the basis of epoxy resin with a modulus of elasticity $E=2.9 \cdot 10^{9} \mathrm{H} / \mathrm{M}^{2}$. Inserts - inclusions were glued with two types of adhesives - rigid two-component Akfix 705 and more plastic one-component 808. The research results were compared with the test data of specimens in which holes were cut from both sides to a depth of $1 / 3$ of the sample thickness. That is, the inclusion in this case was simulated by an insert of the specified thickness, homogeneous with the material, without gluing.

The obtained experimental results are presented in the form of pictures of the distribution of the field of plastic deformations (Fig. 1) and the graph of the dependence of the J-integral on the load (Fig. 2).

The graph consists of two sections, where the linear segment of the graph corresponds to elastic deformations, the value of which was obtained using the stress intensity factor and experimental data (Fig. 1, a-c). The nonlinear segment of the graph corresponds to the elastic-plastic deformation of the material (Fig. 1, $\mathrm{d}-\mathrm{h}$ ) and is determined through the dependences for the J-integral [6].

Brittle fracture occurred when an epoxy resin inclusion with a modulus of elasticity 1.26 times higher than its value for polycarbonate was inserted into a circular hole, as well as gluing of the specimen hole surfaces and inclusion with hard glue. These two factors, in our opinion, at the stage of loading contributed to the accumulation of elastic energy in the zone between the stiffer inclusion and the elastic surface of the specimen. 


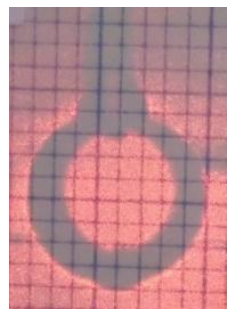

a)

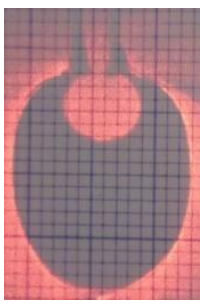

e)

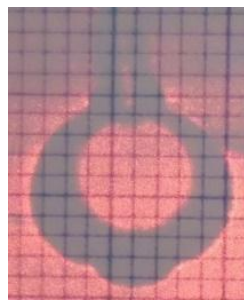

b)

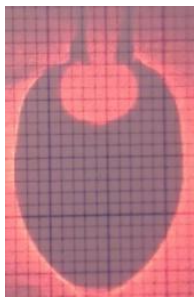

f)

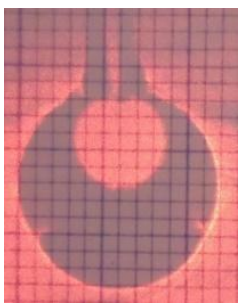

c)

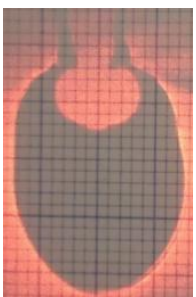

g)

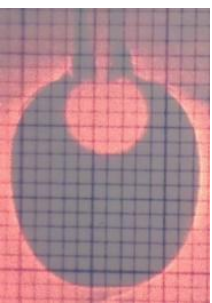

d)

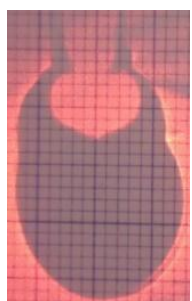

h)

Fig. 1 - Pictures of caustics in the area of the stress concentrator, which are described by the J-integral, with successive magnification load

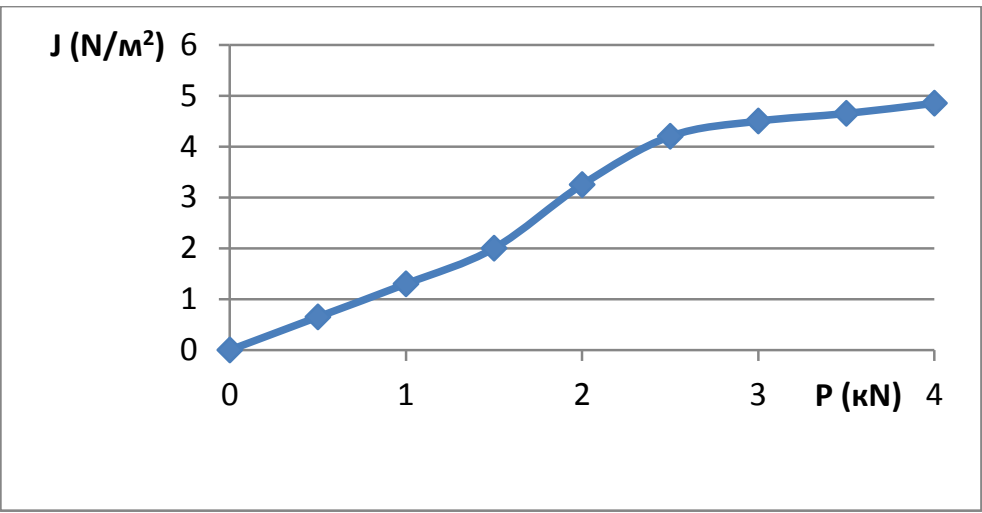

Fig. 2 - Graph of the dependence of the J-integral on the load

Conclusions. According to the results of the studies carried out, it was established:

- the stress-strain state in the vicinity of the crack is largely characterized by the presence of plastic deformations;

- for the J-integral, which is a measure of the deformed state in the vicinity of the crack, linear and nonlinear components can be distinguished de- 
pending on the load level: the first is more responsible for elastic, and the second - for plastic deformations;

- the presence of inclusions in which the modulus of elasticity is greater than in the main body of the specimens, provided that they are fixed in the specimens with the help of rigid adhesives, in contrast to more plastic adhesives, can lead to brittle fracture along the connection line with overgrowth into the main body of the sample;

- the specified sequence of creation of the inclusion can be a trigger mechanism for brittle fracture;

- thinning of the specimens along the line of the main hole leads to a decrease in the breaking load in proportion to the magnitude of the thinning.

The experiments carried out indicate that by changing the stiffness parameters of inclusions and adhesives, it is possible to simulate various aspects of the processes of crack formation in specimens and their destruction.

In general, the results of the experimental studies carried out make it possible to establish the ratio of the values of elastic and plastic deformations during the destruction of specimens and to predict the magnitude of destructive loads.

\section{REFERENCES}

1. Brook D. Fundamentals of fracture mechanics. Tr. from English. Moscow: Vischa shkola, 1980. 386 p. (in Russian).

2. Loboda V.V. et al. Problems of the mechanics of ruining composites with cracks between materials. In the book. Actual problems of the mechanics of ruining: monograph / ed. by M. V. Polyakov. Dnipro: Lira. 2018. P. 277-308. (in Ukrainian).

3. Mechanics of fracture and strength of materials: a reference book at 4-th Vol. / ed. by V.V. Panasyuk. Kiev: Naukova Dumka, 1988. Vol. 2. 620 p. (in Russian).

4. Mossakovsky V.I., Rybka M.T. Generalization of the Griffiths - Sneddon criterion to the case of an inhomogeneous body // Appl. mathematics and mechanics. 1964. Vol. 28. No. 6. P. 1061-1069. (in Russian).

5. Pestrikov V. M., Morozov E. M. Fracture Mechanics of Solids: a course of lectures. St.- Petersburg: Profession, 2002. 320 p. (in Russian).

6 . The way of the combined value of the threshold efficiency of the intensity of the stress in samples from polycarbonate. Patent for Korisna model Ua No. 141655, 04/27/2020. Bul. No. 8. Authors: Dzyuba A.P., Patsyuk A.G., Polishko O.M. (in Ukrainian).

7. Cherepanov G.P. Fracture Mechanics. Izhevsk: Institute of Computer researches, 2012. 872 p. (in Russian).

8. Cherepanov G.P. On the propagation of cracks in a continuous medium // Appl. mathematics and mechanics, 1967. Vol. 31, Iss. 3. P. 111-116. (in Russian).

9. Experimental mechanics: In 2 books: Book 1. Tr. from English / Ed. by A. Kobayashi. Moscow: Mir, 1990. 612 p. (in Russian).

10. Rice J. R. A path independent integral and the approximate analysis of strain concentration by notches and cracks // J. Appl. Mech. 1968. Vol. 35.P. 379-386. (in Russian).

Дніпровський національний університет імені Олеся Гончара, Дніпро. Україна

Надійшла до редколегії 04.10.2021 